\title{
The Effect of Medium Chain Triglyceride upon Fat Absorption and Plasma Lipid and Depot Fat of Children with Cystic Fibrosis of the Pancreas *
}

\author{
Peter T. Kuo $\nmid$ and Nancy N. Huang $\$$ \\ (From the Edward B. Robinette Foundation for Cardiovascular Research, Medical Clinics, \\ Hospital of the University of Pennsylvania, and St. Christophers Hospital for Children. \\ Department of Pediatrics, Temple University Medical School, Philadelphia, Pa.)
}

Impairment of intestinal fat digestion and absorption constitutes one of the principal manifestations of cystic fibrosis of the pancreas $(1,2)$. It has been reported that in these patients, triglycerides of shorter chain fatty acids appear to be more completely absorbed than those containing fatty acids with chain lengths longer than 12 carbon atoms $(3,4)$.

After medium chain triglyceride preparations (MCT), which contain principally caprylic (C8:0) and capric ( $\mathrm{C} 10: 0)$ acids with less than $5 \%$ of $\mathrm{C} 12$ and longer chain acids, ${ }^{1}$ became available, several investigators found them useful in the management of various types of steatorrhea (5-7).

This paper reports on the effect of MCT feeding upon 1) the plasma lipid levels, 2) the fatty acid compositions of the major plasma lipid fractions and the depot fat, and 3) the fecal fat loss and the nutritional status of children with cystic fibrosis of the pancreas.

\section{Methods}

Subjects. Two groups of children who presented typical clinical and laboratory findings of cystic fibrosis of

* Submitted for publication May 14, 1965; accepted August 5, 1965.

Supported by grants from the American Heart Association; grant HE-08805 from the National Heart Institute; and grant 3-MO-1-RR-40 from the Clinical Research Center, Division of Research Facilities and Resources, National Institutes of Health, U. S. Public Health Service.

† Supported by Research Career Development Award 5-K3-AM-17012.

Address requests for reprints to Dr. Peter T. Kuo, Hospital of the University of Pennsylvania, 3400 Spruce St., Philadelphia, $\mathrm{Pa}$.

¥ Supported by a Center Grant, National Cystic Fibrosis Research Foundation; and Clinical Research Center grant FR-75-02, National Institutes of Health.

1 Supplied by Dr. V. Babayan and Mr. A. Robertson, Drew Chemical Co., Boonton, N. J. the pancreas were used in this study. Group 1 consisted of ten children ranging in age from 1 to 11 years. Group 2 contained four young infants from $1 \frac{1}{2}$ to 5 months of age. Pancreatic insufficiency in these children was established by tryptic activity of the duodenal juice and stool fat determinations. For comparison with patients in group 1, we studied blood and depot fat lipids of ten other age-matched children who showed no clinical or laboratory evidence of disturbance in fat digestion and absorption but were convalescing in the hospital from various medical and surgical conditions and consuming a regular mixed diet.

Diet, MCT feedings, and blood, depot fat, and stool samples. During the control period, older children with cystic fibrosis of the pancreas (group 1) and children in the control group received a regular hospital diet consisting of three meals supplemented with 8 ounces of milk with each meal and an extra 8 ounces at 8 p.m. Four cystic fibrosis infants in group $2,1 \frac{1}{2}$ to 5 months old, were fed five times a day with a standard cow's milk formula diet and three supplements of mixed baby food. Two or three blood samples (after a 10- to 12-hour fast) and subcutaneous fat aspirations were taken from each child during this initial period. A 72-hour stool collection was also obtained from each patient. In the MCT feeding period, cow's milk supplement and the standard formula were replaced by an emulsion consisting of $4.5 \%$ of MCT, nonfat milk powder, and small amounts of syrup and artificial flavoring. It was calculated that while on the experimental diet, the four cystic fibrosis infants and the ten older patients would receive a total of 30 to $75 \mathrm{ml}$ of MCT per day, respectively. These levels of fat intake are similar to those which the patients would get from the hospital diet and feeding. Blood, adipose tissue (8), and stool specimens were taken from each of the children at 2- to 3-week intervals for analysis after the start and throughout the MCT treatment period, which lasted from 3 to 5 months. One of the patients received MCT for 9 months. Body weight, stool fat, blood, and depot fat determinations were repeated in both groups of patients for 2 to 3 months after MCT feeding had been stopped.

Laboratory studies. Samples of 72-hour weighed stool specimens, which had been thoroughly mixed by homogenization with appropriate amounts of water, were analyzed for fat content by the method of Van de Kamer 
TABLE I

Effect of medium chain triglyceride ( $M C T$ ) upon the fecal fat content and the weight of children with cystic fibrosis of the pancreas

\begin{tabular}{|c|c|c|c|c|c|c|}
\hline \multirow[b]{2}{*}{ Name } & \multirow[b]{2}{*}{$\begin{array}{c}\text { Age MCT } \\
\text { started }\end{array}$} & \multirow[b]{2}{*}{$\begin{array}{l}\text { Duration of } \\
\text { MCT treatment }\end{array}$} & \multicolumn{2}{|c|}{ Average fecal fat content* } & \multicolumn{2}{|c|}{ Average change in weight } \\
\hline & & & Without MCT & With MCT & $\begin{array}{l}\text { Without } \\
\text { MCT }\end{array}$ & With MCT \\
\hline \multicolumn{3}{|c|}{ 1) Older children } & \multicolumn{2}{|c|}{ g/27 hours } & \multicolumn{2}{|c|}{ lbs/month } \\
\hline $\begin{array}{l}\text { 1) Older } \\
\text { C. K. } \\
\text { R. D. } \\
\text { J. Mc. } \\
\text { F. M. } \\
\text { S. M. } \\
\text { G. C. } \\
\text { H. R. } \\
\text { K. B. } \\
\text { G. D. } \\
\text { A. H. }\end{array}$ & $\begin{array}{r}\text { ren } \\
1 \text { year } \\
5 \text { years } \\
1 \text { year } \\
7 \text { years } \\
6 \text { years } \\
11 \text { years } \\
4 \text { years } \\
1 \text { year } \\
8 \text { years } \\
9 \text { years }\end{array}$ & $\begin{array}{r}9 \text { months } \\
5 \text { months } \\
5 \text { months } \\
3 \text { months } \\
3 \text { months } \\
3 \text { months } \\
3 \frac{1}{2} \text { months } \\
4 \text { months } \\
3 \text { months } \\
4 \text { months }\end{array}$ & $\begin{array}{l}21.9(2) \\
42.6(2) \\
19.9(2) \\
15.0(2) \\
18.3(2) \\
26.7(2) \\
22.8(2) \\
14.7(2) \\
14.4(2) \\
21.7(2)\end{array}$ & $\begin{array}{l}4.1(9) \\
8.0(6) \\
4.9(6) \\
6.1(4) \\
5.2(4) \\
6.2(4) \\
6.5(4) \\
7.1(5) \\
7.2(4) \\
5.4(5)\end{array}$ & $\begin{array}{l}+0.8 \\
+0.3 \\
+0.4 \\
-0.3 \\
-0.9 \\
+0.0 \\
+0.0 \\
+0.3 \\
+0.5 \\
+0.3\end{array}$ & $\begin{array}{l}+1.5 \\
+1.2 \\
+1.0 \\
+1.3 \\
+1.4 \\
+2.5 \\
+1.6 \\
+0.8 \\
+1.3 \\
+1.5\end{array}$ \\
\hline $\begin{array}{l}\text { 2) Infant } \\
\text { N. C. } \\
\text { G. B. } \\
\text { T. L. } \\
\text { L. R. }\end{array}$ & $\begin{array}{r}4 \text { months } \\
3 \frac{1}{2} \text { months } \\
1 \frac{1}{2} \text { months } \\
5 \text { months }\end{array}$ & $\begin{array}{l}6 \text { weeks } \\
6 \text { weeks } \\
6 \text { weeks } \\
6 \text { weeks }\end{array}$ & $\begin{array}{l}3.4(2) \\
6.8(2) \\
4.6(2) \\
9.9(2)\end{array}$ & $\begin{array}{l}0.9(3) \\
0.7(3) \\
1.2(3) \\
1.1(3)\end{array}$ & $\begin{array}{l}+1.1 \\
+1.1 \\
+0.6 \\
+0.8\end{array}$ & $\begin{array}{l}+1.5 \\
+1.8 \\
+1.6 \\
+1.5\end{array}$ \\
\hline
\end{tabular}

* Figures in parentheses indicate the number of stool fat determinations made on the patient.

(9). Red cells were separated from the plasma by centrifugation at $4^{\circ} \mathrm{C}$; the plasma was rapidly frozen and stored at $-18^{\circ} \mathrm{C}$ before analysis. Total plasma lipids were extracted with a Folch chloroform/methanol mixture (10). Plasma neutral lipids and phospholipids were separated by silicic acid thin-layer chromatography (11). After the thin-layer plates had been developed in the prescribed solvent systems, they were lightly sprayed with Rhodamine $G$ to identify and locate the different fractions. Spots containing cholesterol ester, triglyceride, free fatty acid, and lecithin were scraped off the plates separately. Each of the neutral lipid fractions was eluted from the silicic acid powder by chloroform, and lecithin was eluted by $4 \%$ water in methanol. Fatty acid components of the adipose tissue were determined by the method of Farquhar and his associates (12). The method of Stoffel, Chu, and Ahrens (13) was used to prepare methyl esters of the fatty acids present in each of the lipid fractions for analysis by a Barber Colman model 10 gas-liquid chromatograph. Conditions of the chromatography were as follows: stationary phase, $15 \%$ ethylene glycol succinate on Chromosorb W; column, 6 feet, glass; column temperature, $185^{\circ} \mathrm{C}$; argon flow, 80 to $100 \mathrm{ml}$ per minute; amplifier voltage, $500 \mathrm{v}$. The area of each of the $\mathrm{C} 8$ to C20 acid peaks in the chromatogram was determined by the method of triangulation. The areas were then totaled, and the percentage of each component was determined. Percentages of the minor fatty acid fractions, except for stearic, were then summated under two groups: those with chain length shorter than C16 and those having carbon chains longer than 20 carbons.

A dual symbol system with the first number indicating

TABLE II

Plasma lipid levels of children with cystic fibrosis with and without MCT compared with those of controls

\begin{tabular}{|c|c|c|c|c|}
\hline \multirow[b]{2}{*}{ Subject } & \multirow{2}{*}{$\begin{array}{l}\text { No. of } \\
\text { determin- } \\
\text { ations }\end{array}$} & \multicolumn{3}{|c|}{ Plasma lipids } \\
\hline & & Cholesterol & Phospholipid & Triglyceride \\
\hline $\begin{array}{l}\text { Controls, } \\
\text { without steatorrhea }\end{array}$ & 20 & $\begin{array}{c}m g / 100 m l \\
188.8 \pm 32.9^{*} \\
(124-225) \dagger\end{array}$ & $\begin{array}{c}m g / 100 m l \\
211.8 \pm 44.7 \\
(155-283)\end{array}$ & $\begin{array}{c}m g / 100 m l \\
73.7 \pm 18.8 \\
(42-104)\end{array}$ \\
\hline $\begin{array}{l}\text { Cystic fibrotics, } \\
\text { not on MCT }\end{array}$ & 20 & $\begin{array}{r}145.1 \pm 28.5 \\
(108-197)\end{array}$ & $\begin{array}{r}178.0 \pm 23.7 \\
(145-208)\end{array}$ & $\begin{array}{c}81.9 \pm 20.2 \\
(47-114)\end{array}$ \\
\hline $\begin{array}{l}\text { Cystic fibrotics, } \\
\text { on MCT }\end{array}$ & 51 & $\begin{array}{r}148.7 \pm 24.6 \\
(110-179)\end{array}$ & $\begin{array}{r}192.5 \pm 31.6 \\
(150-240)\end{array}$ & $\begin{array}{c}114.0 \pm 35.5 \\
(76-176) \\
\mathrm{p}=<0.100 \ddagger\end{array}$ \\
\hline
\end{tabular}

* Mean \pm standard deviation.

$\dagger$ Range.

$\ddagger \mathrm{p}$ indicates significance of change in serum triglyceride concentration before and after MCT. 
TABLE III

Comparative study of plasma lipids of cystic fibrosis infants with and without MCT feeding

\begin{tabular}{|c|c|c|c|c|c|c|c|}
\hline \multirow[b]{2}{*}{ Name } & \multirow[b]{2}{*}{ Age } & \multicolumn{2}{|c|}{ Cholesterol } & \multicolumn{2}{|c|}{ Phospholipid } & \multicolumn{2}{|c|}{ Triglyceride } \\
\hline & & $\begin{array}{l}\text { Without } \\
\text { MCT }\end{array}$ & $\begin{array}{l}\text { With } \\
\text { MCT }\end{array}$ & $\begin{array}{l}\text { Without } \\
\text { MCT }\end{array}$ & $\begin{array}{l}\text { With } \\
\text { MCT }\end{array}$ & $\begin{array}{l}\text { Without } \\
\text { MCT }\end{array}$ & $\begin{array}{l}\text { With } \\
\text { MCT }\end{array}$ \\
\hline N. C. & 4 months & $\begin{array}{c}122^{*} \\
(113-131) \dagger\end{array}$ & $\begin{array}{c}137 \\
(129-147)\end{array}$ & $\begin{array}{c}168 \\
(165-172)\end{array}$ & $\begin{array}{c}188 \\
(183-200)\end{array}$ & $\begin{array}{c}88 \\
(76-90)\end{array}$ & $\begin{array}{c}184 \\
(140-249)\end{array}$ \\
\hline G. B. & $3 \frac{1}{2}$ months & $\begin{array}{c}147 \\
(130-154)\end{array}$ & $\begin{array}{c}157 \\
\text { (135-188) }\end{array}$ & $\begin{array}{c}168 \\
(158-190)\end{array}$ & $\begin{array}{c}163 \\
(150-170)\end{array}$ & $\begin{array}{c}96 \\
(94-98)\end{array}$ & $\begin{array}{c}118 \\
(96-128)\end{array}$ \\
\hline T. L. & $1 \frac{1}{2}$ months & $\begin{array}{c}128 \\
(117-136)\end{array}$ & $\begin{array}{c}154 \\
(131-167)\end{array}$ & $\begin{array}{c}159 \\
(145-175)\end{array}$ & $\begin{array}{c}195 \\
(183-205)\end{array}$ & $\begin{array}{c}100 \\
(89-112)\end{array}$ & $\begin{array}{c}145 \\
(118-206)\end{array}$ \\
\hline L. R. & 5 months & $\begin{array}{c}121 \\
(118-124)\end{array}$ & $\begin{array}{c}126 \\
(111-135)\end{array}$ & $\begin{array}{c}186 \\
(165-207)\end{array}$ & $\begin{array}{c}174 \\
(150-200)\end{array}$ & $\begin{array}{c}119 \\
(108-130) \\
p=<0\end{array}$ & ${ }^{166}(144-212)$ \\
\hline
\end{tabular}

\section{* Mean value.}

$\dagger$ Range.

$\ddagger p$ indicates significance of change in serum triglyceride concentrations before and after MCT, as determined by the paired $t$ test.

the chain length, and the second the number of double bonds, is used for identifying the fatty acids found. Accuracy of quantification of the acids by gas-liquid chromatography was obtained by calibrating the instrument with U. S. Public Health A-F fatty acid standard. Serum total cholesterol, phospholipid, and triglyceride concentrations were determined by the methods of Abel, Levy, Brodie, and Kendall (14), Zilversmit and Davis (15), and Van Handel (16), respectively.

\section{Results}

Fecal fat content and weight gain. The effects of MCT administration upon fecal fat excretion and the body weight of the two groups of children with cystic fibrosis of the pancreas are shown in Table I. Patients in group 1 were estimated to be excreting on the average 14.4 to $42.6 \mathrm{~g}$ of fat in their stools with a mean excretion for the group of $21.8 \mathrm{~g}$ per 24 hours during periods immediately before and several weeks after the termination of MCT feeding. In comparison, six children ranging from 1 to 11 years of age in the control group excreted 0.9 to $5.9 \mathrm{~g}$ of fat per day with a mean excretion of $3.0 \mathrm{~g}$ per day. Both the control and cystic fibrosis groups of children received a mixed diet with similar fat content, estimated to contain 45 to $75 \mathrm{~g}$ fat per day. MCT feeding improved the steatorrhea and altered the physical characteristics of the stool of each of the ten older cystic fibrosis children within 3 weeks of its initial administration. During the feeding period, their fecal fat content was decreased to 4.9 to $8.0 \mathrm{~g}$ per 24 hours, with a mean of $6.1 \mathrm{~g}$ per 24 hours.

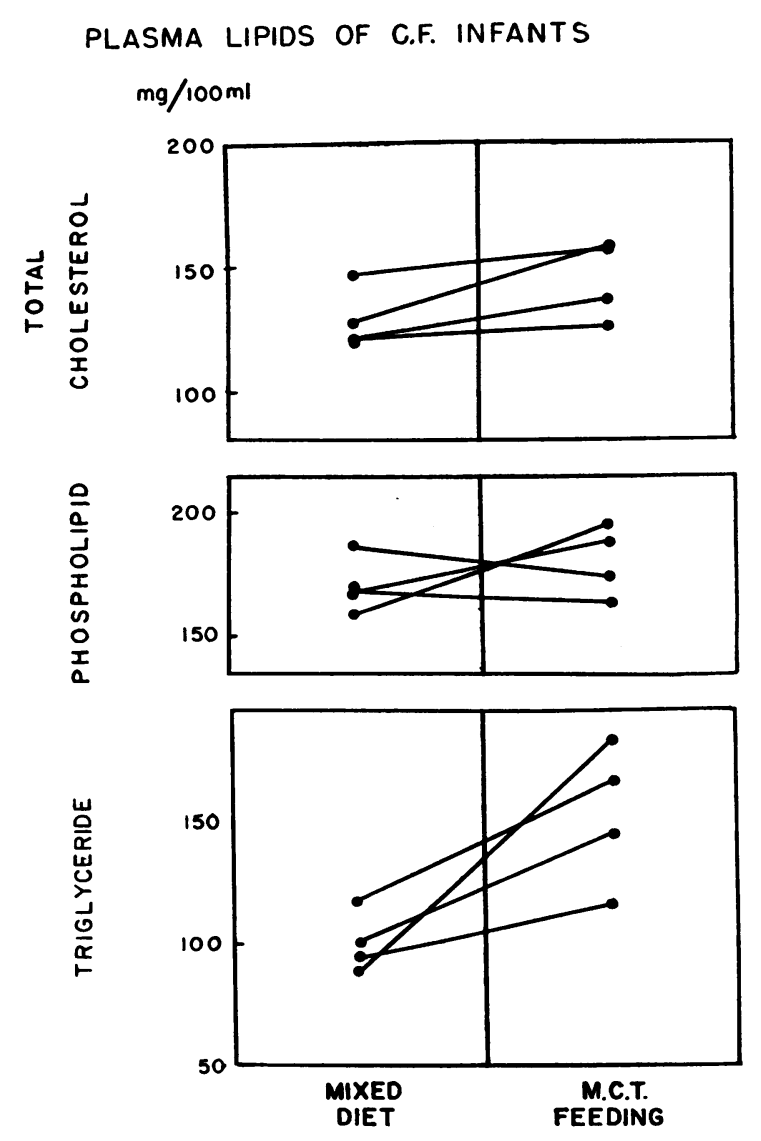

Fig. 1. The mean plasma total cholesterol, phosPHOLIPID, AND TRIGLYCERIDE LEVELS OF EACH OF THE FOUR INFANTS WITH CYSTIC FIBROSIS ON A MIXED DIET AND MEDIUM CHAIN TRIGLYCERIDE (MCT) FEEDING PERIODS. 
The four infants in group 2 excreted only 0.9 to $1.2 \mathrm{~g}$ fat per 24-hour period in their stools while they were receiving the main bulk of their daily fat intake in the form of MCT, which amounted to about $30 \mathrm{~g}$ per day. Although these low levels of fecal fat excretion were most likely due to the relatively low total daily fat intake as compared with that of the older children, these values were significantly lower than the 3.4- to $9.9-\mathrm{g}$ per day level of excretion while they were not receiving MCT treatment.

Despite the fact that all patients studied had variable degrees of pulmonary infection, their nutritional status was improved by MCT administration. Slight to moderate increases in the rate of weight gain were observed in both groups of patients during the MCT feeding periods.

Plasma lipid levels. The plasma total cholesterol, phospholipid, and triglyceride levels of group 1 children with cystic fibrosis of the pancreas, with and without MCT feeding, are tabulated in Table II for comparison with the plasma lipids found in a control group of children not suffering from steatorrhea. Blood samples were taken from these patients for lipid analyses just before MCT administration, after the first 3 weeks, at various intervals throughout the course, and several weeks after its termination. While the children with cystic fibrosis were on a mixed diet, the mean values of their serum cholesterol and phospholipid

TABLE IV

Effects of impaired fat absorption and of MCT upon the fatty acid composition of the plasma lipids in children with cystic fibrosis of the pancreas

\begin{tabular}{|c|c|c|c|c|c|c|c|c|c|c|}
\hline \multirow[b]{2}{*}{ Subjects } & \multirow[b]{2}{*}{ Feedings } & \multirow{2}{*}{$\begin{array}{l}\text { Lipid } \\
\text { fractions }\end{array}$} & \multicolumn{8}{|c|}{$\begin{array}{c}\text { Fatty acids } \\
\text { (mean percentage composition) }\end{array}$} \\
\hline & & & $<\mathrm{C16}$ & C16:0 & C16:1 & C18:0 & C18:1 & C18:2 & $\mathrm{C} 20: 4$ & Others \\
\hline $\begin{array}{l}\text { A) Child- } \\
\text { ren; fat } \\
\text { absorption } \\
\text { normal }\end{array}$ & $\begin{array}{r}\text { Mixed } \\
\text { diet }\end{array}$ & $\begin{array}{l}\text { Free fatty } \\
\text { acid }\end{array}$ & $3.1 \pm 0.5^{*}$ & $35.6 \pm 2.0$ & $4.8 \pm 1.6$ & $10.2 \pm 2.0$ & $36.6 \pm 3.4$ & $10.1 \pm 2.3$ & Trace & \\
\hline \multirow[t]{2}{*}{$\begin{array}{l}\text { Cystic } \\
\text { fbrosis } \\
\text { children }\end{array}$} & $\begin{array}{c}\text { Mixed } \\
\text { diet }\end{array}$ & $\begin{array}{l}\text { Free fatty } \\
\text { acid }\end{array}$ & $\begin{aligned} & 5.2 \pm 1.3 \\
1 \dagger= & <0.001\end{aligned}$ & $36.3 \pm 3.7$ & $\begin{array}{l}6.6 \pm 1.1 \\
<0.01\end{array}$ & $\begin{array}{l}7.8 \pm 1.2 \\
<0.01\end{array}$ & $37.9 \pm 4.2$ & $\begin{array}{l}6.2 \pm 2.0 \\
<0.001\end{array}$ & Trace & \\
\hline & $\begin{array}{l}\text { MCT sup- } \\
\text { plement }\end{array}$ & $\begin{array}{l}\text { Free fatty } \\
\text { acid }\end{array}$ & $\begin{aligned} & 7.4 \pm 2.6 \\
2 \ddagger= & <0.05\end{aligned}$ & $\begin{array}{c}42.7 \pm 8.4 \\
<0.005\end{array}$ & $6.5 \pm 1.1$ & $9.2 \pm 2.6$ & $\begin{array}{c}29.3 \pm 5.3 \\
<0.005\end{array}$ & $\begin{array}{l}4.4 \pm 1.4 \\
<0.010\end{array}$ & Trace & \\
\hline $\begin{array}{l}\text { B) Child- } \\
\text { ren; fat } \\
\text { absorption } \\
\text { normal }\end{array}$ & $\begin{array}{r}\text { Mixed } \\
\text { diet }\end{array}$ & Triglyceride & $3.1 \pm 0.5$ & $32.8 \pm 2.1$ & $4.2 \pm 1.4$ & $4.3 \pm 1.2$ & $42.0 \pm 5.0$ & $13.6 \pm 4.8$ & Trace & \\
\hline \multirow[t]{2}{*}{$\begin{array}{l}\text { Cystic } \\
\text { fibrosis } \\
\text { children }\end{array}$} & $\begin{array}{r}\text { Mixed } \\
\text { diet }\end{array}$ & Triglyceride & $\begin{aligned} & 4.3 \pm 2.0 \\
= & \end{aligned}$ & $34.5 \pm 2.0$ & $\begin{array}{l}6.5 \pm 1.0 \\
<0.001\end{array}$ & $3.7 \pm 1.3$ & $44.4 \pm 2.7$ & $\begin{array}{l}6.7 \pm 2.7 \\
<0.001\end{array}$ & Trace & \\
\hline & $\begin{array}{l}\text { MCT sup- } \\
\text { plement }\end{array}$ & Triglyceride & $=5.1 \pm 2.1$ & $\begin{array}{c}47.5 \pm 4.5 \\
<0.001\end{array}$ & $6.9 \pm 1.2$ & $4.6 \pm 1.9$ & $\begin{array}{c}33.8 \pm 5.0 \\
<0.001\end{array}$ & $\begin{array}{l}2.2 \pm 1.4 \\
<0.001\end{array}$ & Trace & \\
\hline $\begin{array}{l}\text { C) Child- } \\
\text { ren; fat } \\
\text { absorption } \\
\text { normal }\end{array}$ & $\begin{array}{r}\text { Mixed } \\
\text { diet }\end{array}$ & $\begin{array}{l}\text { Cholesterol } \\
\text { ester }\end{array}$ & $1.2 \pm 0.2$ & $13.2 \pm 1.4$ & $3.0 \pm 0.4$ & $1.1 \pm 0.4$ & $19.9 \pm 2.3$ & $52.8 \pm 3.7$ & $7.2 \pm 1.4$ & $1.7 \pm 0.4$ \\
\hline \multirow[t]{2}{*}{$\begin{array}{l}\text { Cystic } \\
\text { fibrosis } \\
\text { children }\end{array}$} & $\begin{array}{r}\text { Mixed } \\
\text { diet }\end{array}$ & $\begin{array}{l}\text { Cholesterol } \\
\text { ester }\end{array}$ & $=2.1 \pm 0.9$ & $\begin{array}{c}16.3 \pm 2.4 \\
<0.005\end{array}$ & $\begin{array}{c}9.2 \pm 4.2 \\
<0.001\end{array}$ & $1.2 \pm 0.4$ & $\begin{array}{c}31.3 \pm 7.1 \\
<0.001\end{array}$ & $\begin{array}{c}32.6 \pm 9.6 \\
<0.001\end{array}$ & $\begin{array}{c}5.4 \pm 1.5 \\
<0.025\end{array}$ & $2.1 \pm 0.5$ \\
\hline & $\begin{array}{l}\text { MCT sup- } \\
\text { plement }\end{array}$ & $\begin{array}{l}\text { Cholesterol } \\
\text { ester }\end{array}$ & $=\begin{aligned} & 3.1 \pm 1.6\end{aligned}$ & $17.6 \pm 4.0$ & $\begin{array}{c}17.0 \pm 5.7 \\
<0.005\end{array}$ & $1.5 \pm 0.7$ & $\begin{array}{c}36.1 \pm 8.2 \\
<0.025\end{array}$ & $\begin{array}{c}19.2 \pm 8.5 \\
<0.001\end{array}$ & $\begin{array}{c}3.5 \pm 2.7 \\
<0.025\end{array}$ & $2.0 \pm 1.2$ \\
\hline $\begin{array}{l}\text { D) Child- } \\
\text { ren; fat } \\
\text { absorption } \\
\text { normal }\end{array}$ & $\underset{\text { diet }}{\text { Mixed }}$ & Lecithin & $1.6 \pm 0.3$ & $36.0 \pm 2.0$ & $1.7 \pm 0.2$ & $14.6 \pm 1.3$ & $13.2 \pm 2.1$ & $19.3 \pm 2.0$ & $10.6 \pm 2.2$ & $3.2 \pm 0.9$ \\
\hline \multirow[t]{2}{*}{$\begin{array}{l}\text { Cystic } \\
\text { fibrosis } \\
\text { children }\end{array}$} & $\begin{array}{r}\text { Mixed } \\
\text { diet }\end{array}$ & Lecithin & $p_{1}=r \pm 0.7$ & $\begin{array}{c}41.3 \pm 2.9 \\
<0.001\end{array}$ & $2.1 \pm 0.5$ & $\begin{array}{c}12.0 \pm 2.0 \\
<0.005\end{array}$ & $\begin{array}{c}17.2 \pm 3.4 \\
<0.005\end{array}$ & $\begin{array}{c}12.5 \pm 3.0 \\
<0.001\end{array}$ & $\begin{array}{l}8.3 \pm 2.5 \\
<0.05\end{array}$ & $3.8 \pm 1.7$ \\
\hline & $\begin{array}{l}\text { MCT sup- } \\
\text { plement }\end{array}$ & Lecithin & $p_{2}={ }^{2.1 \pm 1.2}$ & $\begin{array}{c}45.9 \pm 2.5 \\
<0.005\end{array}$ & $\begin{array}{l}3.1 \pm 1.2 \\
<0.025\end{array}$ & $\begin{array}{l}9.9 \pm 1.7 \\
<0.025\end{array}$ & $\begin{array}{c}23.0 \pm 5.4 \\
<0.005\end{array}$ & $\begin{array}{c}8.0 \pm 2.3 \\
<0.001\end{array}$ & $\begin{array}{c}4.7 \pm 2.1 \\
<0.005\end{array}$ & $3.4 \pm 1.8$ \\
\hline
\end{tabular}

* Mean \pm standard deviation.

$t p_{1}$ indicates significance of change between cystic fibrosis children and the controls. $\ddagger \mathrm{p}_{2}$ indicates significance of change between cystic fibrosis children before and after MCT. 


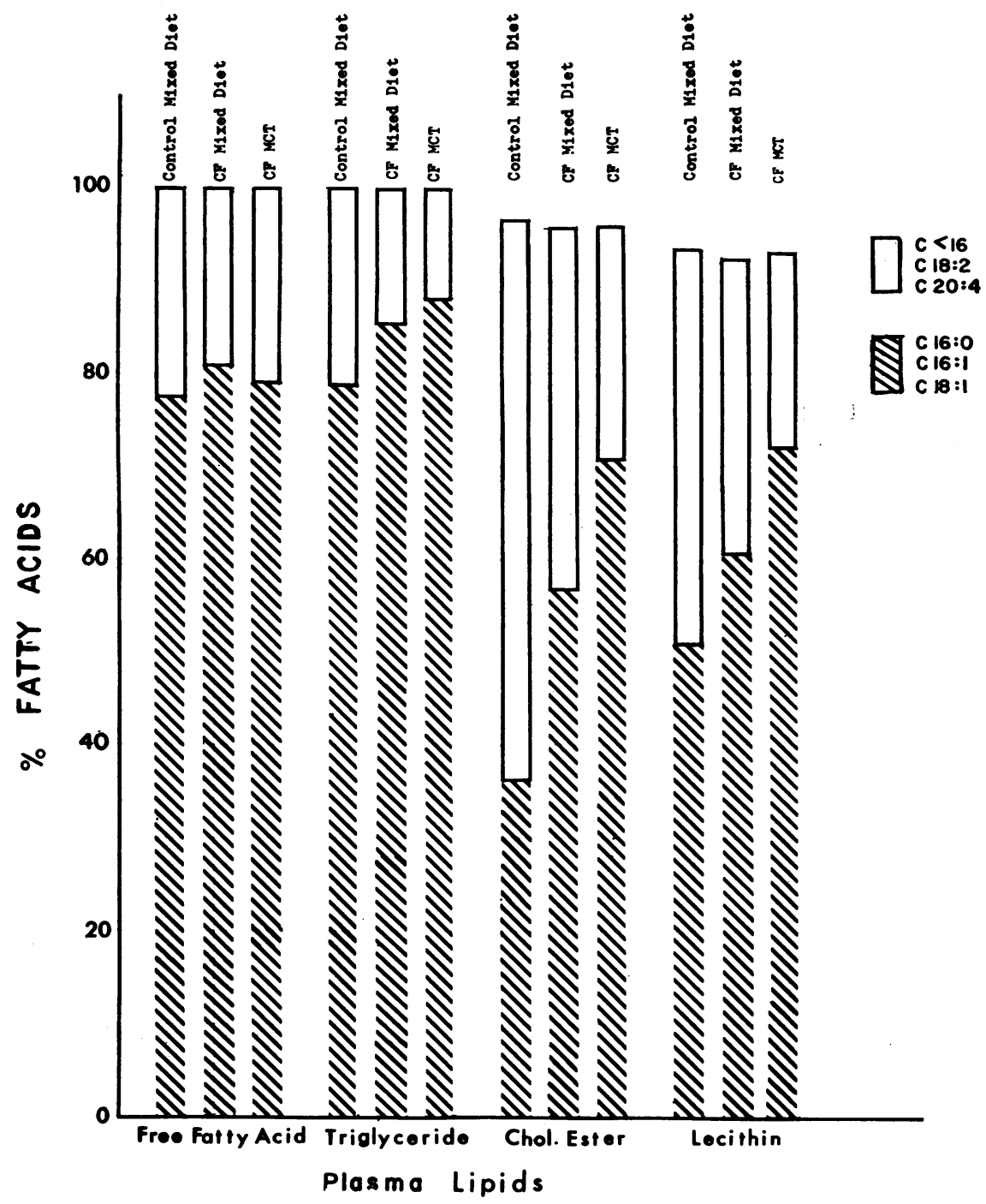

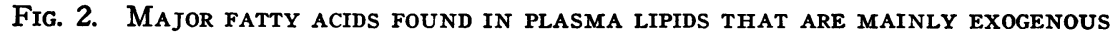
IN ORIGIN (C< $<6, \mathrm{C} 18: 2, \mathrm{C} 20: 4$, OPEN PORTION OF EACH BAR) AND THOSE THAT ARE MAINLY ENDOGENOUS IN ORIGIN (C16:0, C16:1, AND C18: 1, HATCHED PORTION OF THE BAR). Charted for comparison are changes in the relative proportions of the exogenous and the endogenous groups of fatty acids in plasma free fatty acid, triglyceride, cholesterol ester, and lecithin of normal children on a mixed diet, and children with cystic fibrosis (CF) on a mixed diet and on MCT feeding.

levels were slightly but not significantly lower than the respective values of the children in the control group. The mean plasma triglyceride concentrations of the two groups of children were quite similar. Supplementary MCT feeding did not cause a noticeable change in either the plasma cholesterol or the phospholipid values of the children with cystic fibrosis. Its administration appeared to result in some elevation of the mean plasma triglyceride level of these patients. However, the ranges of variation of their plasma triglyceride values were large; hence, the significance of the change was found to be low $(p<0.10)$.

Four cystic fibrosis infants with relatively mild degrees of pulmonary disease were placed on MCT formula feeding for 6 weeks to obtain more definitive information on the effect of MCT upon their plasma lipid levels. Table III shows the plasma 
lipid levels of these infants taken at periods when they were on and off MCT therapy. The data show that high MCT feeding can induce a mild elevation of the plasma triglyceride level in these patients (Table III and Figure 1). By the paired $t$ test these data were significant at $\mathrm{p}<0.05$.

Fatty acid composition of the plasma lipids. The effects of impaired fat absorption in children with cystic fibrosis of the pancreas and of MCT feeding upon the fatty acid compositions of the plasma free fatty acid, triglyceride, cholesterol ester, and lecithin are shown in Table IV. The data presented confirm the previous observation (17) that impaired fat digestion and absorption produce a heightened endogenous lipogenesis, manifested by increasing the proportions of saturated and monounsaturated $\mathrm{C} 16$ and $\mathrm{C} 18$ fatty acids and decreasing the percentages of linoleic and arachidonic (C18:2 and $\mathrm{C} 20: 4$ ) acids in the plasma lipids. MCT feeding produced the expected increase in short chain fatty acids (fatty acids $<$ C16, Table IV, section A) in plasma free fatty acid, and further significant increases of one or more of the endogenously synthesized C16 and C18 (palmitic 16:0, palmitoleic 16:1, and oleic 18:1) fatty acids, together with sharp decreases in the polyenoic acids (C18:2 and C20:4) in the different plasma lipid fractions of these patients. The degrees of significance of these changes were calculated, and $p$ values are shown in Table IV.

The component fatty acids of the patients' plasma lipids presented in Table IV are segregated into the "endogenously synthesized" (C16:0, $\mathrm{C} 16: 1$, and $\mathrm{C} 18: 1$ ) and the "exogenously derived" (carbon chain < C16, C18:2, and C20:4, a derivative of $\mathrm{C} 18: 2$ ) groups. The charts in Figure 2 provide a rapid comparative study of the effects of impaired fat absorption and of MCT feeding upon the relative proportions of "endogenous" and "exogenous" groups of fatty acids found in the plasma lipids of these patients. In the patients' free fatty acid fraction, where the relative increases in endogenous fatty acids were neutralized by increases in the $\mathrm{C}<16$ fatty acids (derived from milk and MCT), the chart fails to demonstrate the exaggerated lipogenic effect of MCT. However, the diagram is useful in indicating that in impaired fat absorption the proportions of endogenous fatty acids are increased, and percentages of the exogenous acids are decreased in the plasma triglyceride, cholesterol ester, and lecithin of these patients. These changes are exaggerated in children with cystic fibrosis of the pancreas by MCT feeding.

Fatty acid composition of the adipose tissue. Significant alterations in the fatty acid composition of the adipose tissue were demonstrated in these cystic fibrosis children as early as 3 to 4 weeks after the initiation of MCT feeding. Table V lists the mean percentage compositions of the major fatty acids found in the depot fat of these patients before, at various intervals during the 3 to 5 months of MCT therapy, and 2 to 3 months after the termination of MCT treatment. Comparative study of the two fatty acid patterns obtained in these patients while they were on a mixed diet and on MCT shows that MCT ingestion produced 1) a moderate increase in fatty acids with carbon chain length shorter than $\mathrm{C} 16$ due to the incorporation into adipose tissue of a small amount of the shorter chain fatty acids derived from MCT, and 2) a highly significant increase in the palmitic acid $(\mathrm{C} 16: 0)$ content. Increases in these fatty acids resulted in relative decreases in the propor-

TABLE V

Fatty acid composition of adipose tissue in children with cystic fibrosis of pancreas before and after $M C T$ feeding

\begin{tabular}{|c|c|c|c|c|c|c|}
\hline \multirow[b]{2}{*}{ Feeding } & \multicolumn{6}{|c|}{$\begin{array}{l}\text { Fatty acids } \\
\text { (percentage composition) }\end{array}$} \\
\hline & $<\mathrm{C} 16$ & C16:0 & C16:1 & C18:0 & C18:1 & C18:2 \\
\hline On mixed diet & $6.4 \pm 2.8^{*}$ & $30.0 \pm 5.9$ & $8.3 \pm 1.7$ & $3.2 \pm 0.9$ & $46.0 \pm 7.0$ & $6.0 \pm 1.5$ \\
\hline \multirow[t]{2}{*}{$\begin{array}{l}\text { With MCT } \\
\text { supplement }\end{array}$} & $7.7 \pm 2.5$ & $34.2 \pm 8.1$ & $7.5 \pm 0.6$ & $3.8 \pm 1.1$ & $41.3 \pm 9.3$ & $5.5 \pm 1.4$ \\
\hline & $<0.025 \dagger$ & $<0.005$ & & & $<0.025$ & \\
\hline
\end{tabular}

* Mean \pm standard deviation.

$t p$ indicates significance of change of a given fatty acid component after MCT feeding. 


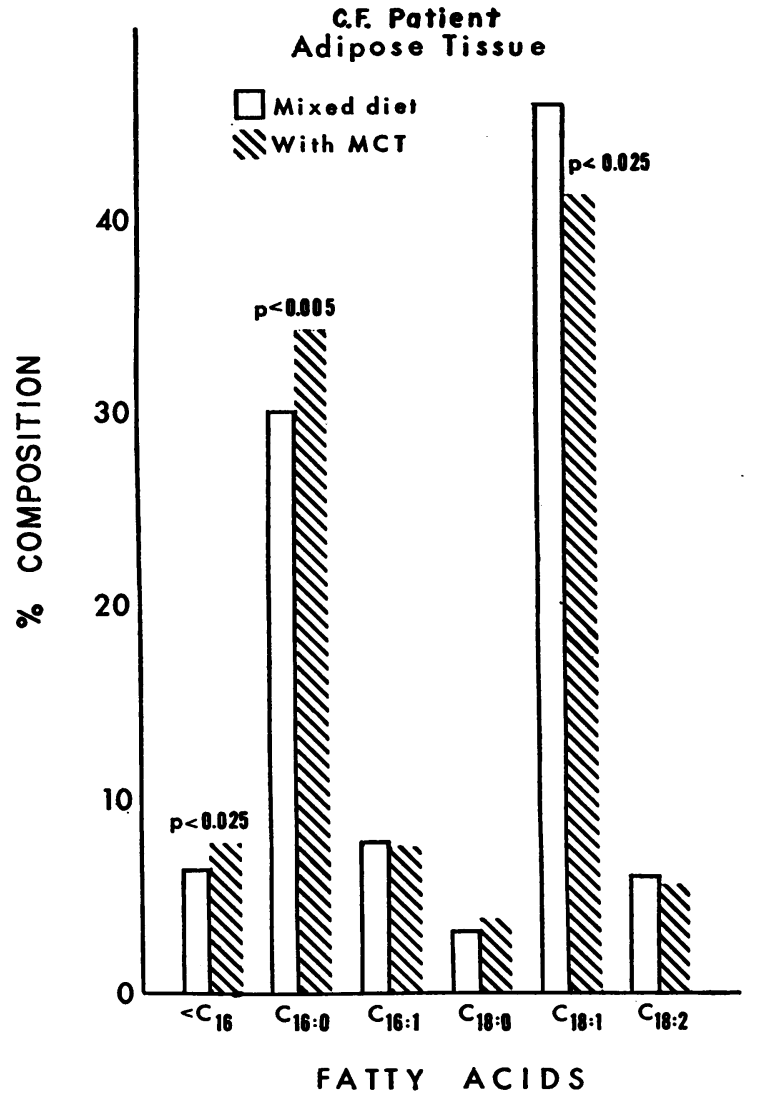

Fig. 3. ThE FATTY ACID COMPOSITION OF THE DEPOT FAT OF CHILDREN WITH CYSTIC FIBROSIS OF THE PANCREAS. The pattern obtained while they were on a mixed diet (open bars) is compared with that obtained on the same patients while they were on MCT feeding (hatched bars). $p$ value indicates the significance of change observed in a given fatty acid component.

tions of the other fatty acids and particularly in the oleic acid (C18:1) percentages in the depot fat of these patients. The two depot fat fatty acid patterns obtained in these patients with and without MCT feeding are charted in Figure 3.

Complication of $M C T$ feeding. The main problem in MCT feeding has been inducing the older children to accept the MCT emulsion, which is palatable, as they do cow's milk, to which they are accustomed. Two patients developed watery diarrhea while receiving MCT feeding. The diarrhea showed partial improvement after the feeding had been stopped. Since the patients were also receiving tetracycline to control their chronic pulmonary infection, the watery diarrhea may have been in part related to the antibiotic therapy.

\section{Discussion}

Earlier studies indicate that, unlike the long chain dietary triglycerides, medium and short chain fats ( 10 and shorter) are mainly absorbed as free fatty acids into the portal circulation (1822). Significantly, Playoust and Isselbacher (23) recently reported the direct absorption of unhydrolyzed shorter chain triglyceride into the intestinal mucosa with subsequent hydrolysis taking place intracellularly by a mucosal lipase. These physiologic characteristics of the shorter chain triglycerides suggest their usefulness in patients with impaired fat absorption due to pancreatic insufficiency. Clinical application of this mechanism has been attempted by Van de Kamer and associates $(3,4)$, who studied indexes of absorption of different fats in children with steatorrhea, and by Hashim, Iber, Pinter, and their respective associates (5-7), who used MCT to treat a few isolated cases of pancreatogenous steatorrhea. The present study indicates that it is feasible to use MCT feeding for a prolonged period of time to control steatorrhea and to increase the daily caloric intake of children with cystic fibrosis of the pancreas.

It must be emphasized that despite the already depressed plasma and tissue polyunsaturated fatty acid levels encountered in these children with impaired fat absorption, further decreases in the relative proportions of linoleic and arachidonic acids after MCT feeding for a period of 5 to 9 months not only did not precipitate clinical manifestations of essential fatty acid deficiency, but the feeding actually helped to promote growth and development in these patients. Apparently, the requirements of these "essential" fatty acids are low, and the relatively depressed concentrations of these acids are compatible with good health for a long time. Since it is generally known that some pancreatic function is usually preserved in most of these patients and that patients with steatorrhea generally exhibit a selective absorption of fats containing fatty acids with more than one double bond $(3,4,17)$, the relatively depressed levels in the blood and tissue of these patients should be readily restored to normal by periods of polyunsaturated oil feeding.

Since it has been shown that MCT is absorbed as free fatty acids into the liver and rapidly oxidized, it seems likely that the main bulk of the fed 
$\mathrm{C} 8$ and $\mathrm{C} 10$ fatty acids must undergo preliminary oxidation to 2-carbon fragments for de novo synthesis of palmitic and other long chain fatty acids. However, this study does not exclude the possibility that a small portion of the medium chain fatty acids might also be elongated to $\mathrm{C} 16$ and other long chain acids by different biosynthetic systems recently described in the liver cells $(24$, 25). This hepatic lipogenesis seems to provide adequate explanation for the relative increases in the saturated and monounsaturated fatty acids found in the various plasma lipid fractions of these children after MCT treatment.

It has been shown that patients suffering from disturbances in fat digestion and absorption frequently exhibit a selective absorption of fats with low molecular weight $(3,4)$, and that these low molecular weight short chain triglycerides are absorbed chiefly as free fatty acids into the portal circulation (18-22). Some spillage of these fatty acids into the bloodstream may be expected with high MCT feeding. These pathophysiologic phenomena would acount for the increases in the shorter chain fatty acids (acids having carbon chain lengths $<\mathrm{C} 16$, Table I) in the plasma free fatty acid fraction of milk-fed children, and for the exaggeration of these findings in children with cystic fibrosis of the pancreas with MCT feeding.

At least two physiologic mechanisms may be operative in inducing early changes in the depot fat composition of children with cystic fibrosis by MCT feeding. One factor is related to the rapid increase of new tissue mass occurring in all growing children as suggested by Sweeney and his associates (26). The other more potent mechanism is the absorption of sufficient MCT calories by these malnourished children to maintain a positive metabolic balance.

The finding of only a minor increase in the short chain fatty acids with a significantly large increase in the palmitic acid (C16:0), together with a moderate decrease in the oleic acid (C18:1) in the depot fat of these children with MCT feeding, suggests that the ingested caprylic and capric ( $\mathrm{C} 8$ and $\mathrm{C} 10$ ) acids are chiefly converted into 2-carbon radicals in the liver for the synthesis of palmitic acid (C16:0) by the liver and adipose tissue. Hirsch and Goldrick (27) have likewise reported a preponderance of $\mathrm{C} 16: 0$ acid synthesis from glucose and acetate by study- ing aspirated samples of human adipose tissue. However, in their experimental systems, small amounts of $\mathrm{C} 14$ and C18 saturated and monounsaturated acids were also believed to be generated.

Currently, much attention has been given to the alleged association between dietary fats, plasma lipids, and atherosclerosis. One of the several properties of fats that is known to have an effect upon human plasma lipid level is the average chain length of their constituent fatty acids. At present, there is considerable controversy on what effect MCT may exert upon the plasma lipid levels in man (28-30). In this study, the use of infants with cystic fibrosis who do not have severe pulmonary lesions and do not ingest foods containing large amounts of poorly absorbed fats has surmounted the difficulty of administering sufficient MCT calories to maintain adequate nutrition in the experimental subjects. Under these optimal feeding conditions, MCT has been shown to be capable of inducing mild elevations of serum triglyceride levels of these children. Also, the fatty acid compositions of plasma and depot fat of children receiving MCT feeding were found to closely simulate those described in conditions where lipogenesis from carbohyrate is known to be increased (8, 31-34). These observations suggest that foods with high shorter chain fatty acid content may act in a manner similar to carbohydrates, such as sugars, in stimulating active endogenous lipogenesis to produce hyperlipidemia in individuals who have an inherent tendency to develop hyperglyceridemia.

\section{Summary}

1. The study deals with the effect of medium chain triglyceride (MCT) feeding upon the fecal fat loss, nutritional status, plasma, and adipose tissue lipids of children with cystic fibrosis of the pancreas.

2. MCT feeding reduced steatorrhea and increased the rate of weight gain in all of the patients studied. These changes were particularly impressive in infants with cystic fibrosis who received practically the entire portion of their daily fat intake as MCT.

3. Supplementary MCT feeding did not cause a significant change in the plasma lipid levels of older children with cystic fibrosis. However, feeding of infants with an optimal amount of MCT 
formula diet resulted in mild elevations in their plasma triglyceride levels.

4. Analysis of the fatty acid compositions of the plasma lipids and depot fat of these patients revealed only a small increase in < C16 fatty acids in their body fat and their plasma free fatty acid fraction. We suggest that the ingested MCT was first oxidized to 2-carbon fragments in the liver for use in the synthesis of palmitic (C16:0), palmitoleic (C16:1), and oleic (C18:1) acids. One or more of the endogenously synthesized acids predominated in the fatty acid pattern of the various plasma lipids and the depot fat.

5. The increased endogenous lipogenesis with MCT feeding resulted in proportional decreases of the originally low polyunsaturated (linoleic $\mathrm{C} 18: 2$ and arachidonic C20:4) fatty acids in these children. Despite such changes, the children showed no manifestations of essential fatty acid deficiency.

6. The data suggest that a restriction in foods containing shorter chain fatty acids may be helpful in the dietary control of hyperglyceridemia.

\section{Acknowledgment}

We are grateful to Dr. K. T. Sheng for his help in the clinical aspects of this study.

\section{References}

1. Fanconi, G., E. Uehlinger, and C. Knauer. Das Coeliakiesyndrom bei angeborener zysticher Pankreasfibromatose und Bronchiektasien. Wien. med. Wschr. 1936, 86, 753.

2. Andersen, D. H. Cystic fibrosis of the pancreas and its relation to celiac disease. A clinical and pathological study. Amer. J. Dis. Child. 1938, 56, 344.

3. Van de Kamer, J. H., and H. A. Weijers. Malabsorption syndrome. Fed. Proc. 1961, 20 (suppl. 7), 335.

4. Fernandes, J., J. H. Van de Kamer, and H. A. Weijers. Differences in absorption of the various fatty acids studied in children with steatorrhea. J. clin. Invest. 1962, 41, 498.

5. Hashim, S. A., H. B. Roholt, and T. B. Van Itallie. Pancreatogenous steatorrhea treated with medium chain triglyceride. Clin. Res. 1962, 10, 394.

6. Iber, F. L., E. Hardoon, and M. H. Sangree. Use of eight and ten carbon fatty acids as neutral fat in the management of steatorrhea (abstract). Clin. Res. 1963, 11, 185.

7. Pinter, K. G., B. H. McCracken, C. Lamar, Jr., and G. A. Goldsmith. Fat absorption studies in various forms of steatorrhea. Amer. J. clin. Nutr. 1964, 15, 293.
8. Hirsch, J., J. W. Farquhar, E. H. Ahrens, Jr., M. L. Peterson, and W. Stoffel. Studies of adipose tisue in man: a microtechnic for sampling and analysis. Amer. J. clin. Nutr. 1960, 8, 499.

9. Van de Kamer, J. H. Standard Methods of Clinical Chemistry. New York, Academic Press, 1958, vol. 2, p. 34 .

10. Folch, J., M. Lees, and G. H. Stanley Sloane. A simple method for isolation and purification of total lipids from animal tissues. J. biol. Chem. 1957, 226, 497.

11. Vogel, W. C., W. M. Doizaki, and L. Zieve. Rapid thin-layer chromatographic separation of phospholipids and neutral lipids of serum. J. Lipid Res. $1962,3,138$.

12. Farquhar, J. W., W. Insull, Jr., P. Rosen, W. Stoffel, and E. H. Ahrens, Jr. The analysis of fatty acid mixtures by gas-liquid chromatography: construction and operation of an ionization chamber instrument. Nutr. Rev. 1959, 17 (suppl.), 1.

13. Stoffel, W., F. Chu, and E. H. Ahrens, Jr. Analysis of long-chain fatty acids by gas-liquid chromatography: micromethod for preparation of methyl esters. Analyt. Chem. 1959, 31, 307.

14. Abell, L. L., B. B. Levy, B. B. Brodie, and F. E. Kendall. A simplified method for the estimation of total cholesterol in serum and demonstration of its specificity. J. biol. Chem. 1952, 195, 357.

15. Zilversmit, D. B., and A. K. Davis. Microdetermination of plasma phospholipids by trichloracetic acid precipitation. J. Lab. clin. Med. 1950, 35, 155.

16. Van Handel, E. Suggested modifications of the microdetermination of triglycerides. Clin. Chem. 1961, 7, 249.

17. Kuo, P. T., N. N. Huang, and D. R. Bassett. The fatty acid composition of the serum chylomicrons and adipose tissue of children with cystic fibrosis of the pancreas. J. Pediat. 1962, 60, 394.

18. Bloom, B., I. L. Chaikoff, and W. O. Reinhardt. Intestinal lymph as pathway for transport of absorbed fatty acids of different chain lengths. Amer. J. Physiol. 1951, 166, 451.

19. Bergström, B. Transport of ${ }^{14} \mathrm{C}$-decanoic acid in porta and inferior vena cava blood during absorption in the rat. Acta physiol. scand. 1955, 34, 71.

20. Blomstrand, R., N. A. Thorn, and E. H. Ahrens, Jr. The absorption of fats, studied in a patient with chyluria. I. Clinical investigation. Amer. J. Med. 1958, 24, 958.

21. Fernandes, J., J. H. Van de Kamer, and H. A. Weijers. The absorption of fats studied in a child with chylothorax. J. clin. Invest. 1955, 34, 1026.

22. Hashim, S. A., H. B. Roholt, V. K. Babayan, and T. B. Van Itallie. Treatment of chyluria and chylothorax with medium-chain triglyceride. New Engl. J. Med. 1964, 270, 756.

23. Playoust, M. R., and K. J. Isselbacher. Studies on the intestinal absorption and intramucosal lipolysis 
of a medium chain triglyceride. J. clin. Invest. $1964,43,878$.

24. Harlan, W. R., Jr., and S. J. Wakil. Synthesis of fatty acids in animal tissues. I. Incorporation of $\mathrm{C}^{14}$-acetyl coenzyme $\mathrm{A}$ into a variety of long chain fatty acids by subcellular particles. J. biol. Chem. 1963, 238, 3216.

25. Wakil, S. J. Mechanisms of fatty acid synthesis. J. Lipid Res. 1961, 2, 1.

26. Sweeney, M. J., N. J. Etteldorf, L. J. Throop, D. L. Timma, and E. L. Wrenn. Diet and fatty acid distribution in subcutaneous fat in the cholesteroltriglyceride fraction of serum of young infants. J. clin. Invest. 1963, 42, 1.

27. Hirsch, J., and R. B. Goldrick. Serial studies of metabolism of human adipose tissue. I. Lipogenesis and free fatty acid uptake and release in small aspirated samples of subcutaneous fat. J. clin. Invest. 1964, 43, 1776.

28. Hashim, S. A., A. Arteaga, and T. B. Van Itallie. Effect of saturated medium-chain triglyceride on serum-lipids in man. Lancet 1960, 1, 1105.
29. Beveridge, J. M. R., W. F. Connell, H. L. Haust, and G. A. Mayer. Dietary cholesterol and plasma cholesterol levels in man. Canad. J. Biochem. 1959, $37,575$.

30. Uzawa, H., G. Schlierf, S. Chirman, G. Michaels, P. Wood, and L. W. Kinsell. Hyperglyceridemia resulting from intake of medium chain triglycerides. Amer. J. clin. Nutr. 1964, 15, 365.

31. Kuo, P. T., N. N. Huang, and D. R. Bassett. Effect of impaired fat absorption upon the fatty acid composition of serum chylomicra and adipose tissue in cystic fibrosis of the pancreas. Trans. Ass. Amer. Phycns 1961, 74, 147.

32. Ahrens, E. H., J. Hirsch, K. Oette, J. W. Farquhar, and Y. Stein. Carbohydrate-induced and fat-induced lipemia. Trans. Ass. Amer. Phycns 1961, 74, 134.

33. Kuo, P. T., and D. R. Bassett. Primary hyperlipidemias and their management. Ann. intern. Med. 1963, 59, 495.

34. Kuo, P. T., and D. R. Bassett. Dietary sugar in the production of hyperglyceridemia. Ann. intern. Med. 1965, 62, 1199. 